\title{
PRODUCTION OF MINI-CUTTINGS AND THE INFLUENCE OF LEAF REDUCTION ON ROOTING OF VINHÁTICO (Plathymenia foliolosa Benth.) ${ }^{1}$
}

Victor de Freitas Neubert ${ }^{2 *}$, Aloísio Xavier ${ }^{2}$, Haroldo Nogueira de Paiva $^{2}$, Poliana Coqueiro Dias ${ }^{3}$ and Ricardo Gallo ${ }^{2}$

\footnotetext{
${ }^{1}$ Received on 13.05.2015 accepted for publication on 24.03.2017.

${ }^{2}$ Universidade Federal de Viçosa, Departamento de Engenharia Florestal,Viçosa, Minas Gerais,Brasil. E-mail:<vneubert@hotmail.com>, <xavier@ufv.br>, <hnpaiva@ufv.br>and<gallo.florestal@yahoo.com.br>.

${ }^{3}$ Universidade Federal Rural do Semi-Árido, Departamento de Ciências Vegetais, Mossoró, Rio Grande do Norte,Brasil. Email:<poliana.coqueiro@ufersa.edu.br>.

*Corresponding author.
}

\begin{abstract}
The objective of this work was to evaluate the production and survival of the mini-stumps in mini-clonal hedge and the effect of leaf reduction of mini-cuttings on rooting and seedling growth of progenies of Vinhático (Plathymenia foliolosa) by mini-cutting. Apical mini-cuttings were used to evaluate the influence of leaf reduction on the rooting of vinhático; the mini-cuttings ranged between 8 to $10 \mathrm{~cm}$ in length and samples were subjected to $100 \%$ leaf reduction (without leaf), $75 \%$ of leaf reduction, or no leaf reduction. As for the survival of mini-stumps in mini-clonal hedge, after the fourth successive mini-cuttings collection, P3 and P19 progenies showed the highest survival percentages ( $64.5 \%$ and $61.5 \%$, respectively), while progenies P1 $(32.3 \%)$ and P45 (25\%) showed the lowest values for this parameter. The average number of minicuttings/mini-stump/collection produced ranged from 0.83 (progeny 53) to 4.8 (progeny 01 ) and the average productivity was $120 \mathrm{~m}^{2}$ mini-stumps/mini-cuttings per collection. These results suggest that leaf reduction in adventitious rooting in mini-cuttings did not result in any difference between foliar treatments without reduction and $75 \%$ leaf reduction; however, $100 \%$ mortality was observed when the mini-cuttings were made with total leaf reduction. The progenies studied showed potential regeneration of mini-stumps, thus allowing the realization of successive collections of young shoots.
\end{abstract}

Keywords: Clonal forestry; Vegetative propagation; Cloning.

\section{PRODUÇÃO DE MINIESTACAS E O EFEITO DA REDUÇÃO FOLIAR NO ENRAIZAMENTO DE VINHÁTICO (Plathymenia foliolosa Benth.)}

\begin{abstract}
RESUMO-Objetivou-se com o presente estudo avaliar a produção e sobrevivência de minicepas em minijardim clonal e o efeito da redução foliar das miniestacas no enraizamento e crescimento das mudas de progênies de vinhático (Plathymenia foliolosa) via miniestaquia. Foram utilizadas miniestacas da parte apical com altura variando de 8 a $10 \mathrm{~cm}$ de comprimento, sendo os tratamentos constituídos por $100 \%$ de redução foliar (sem folha), com $75 \%$ de redução foliar e sem redução foliar. Quanto à sobrevivência das minicepas em minijardim clonal, após a quarta coleta sucessiva de miniestacas, as progênies P3 e P19 apresentaram os maiores percentuais de sobrevivência $(64,5 \%$ e 61,5\%, respectivamente), enquanto as progênies P1 (32,3\%) e P45 (25\%), os menores valores observados quanto a essa avaliação. O número médio de miniestacas/ minicepa/coleta produzidas variou de 0,8 (progênie 53) a 4,8 (progênie 01), sendo a produtividade média das minicepas $/ \mathrm{m}^{2}$ de 120 miniestacas por coleta. Com base nos resultados obtidos, concluiu-se que há influência da redução foliar das miniestacas no enraizamento adventício, que os tratamentos sem redução foliar e com $75 \%$ de redução não apresentaram diferenças significativas, no entanto, foi observado $100 \%$ de mortalidade das miniestacas quando feita a redução total das folhas. Concluiu-se também que as progênies estudadas apresentaram potencial quanto à regeneração das minicepas, permitindo, assim, a realização de coletas sucessivas de brotações juvenis.
\end{abstract}

Palavras-chave: Silvicultura clonal; Propagação vegetativa; Clonagem. 


\section{INTRODUCTION}

The last few decades has witnessed the continuous use of the native forest species together with the deforestation aimed at the implantation of pastures and agricultural crops, which has resulted in a drastic reduction in the area of the native forests around the world (Gatti, 2002). Moreover, there is an increased demand for diverse products provided by forest species, such as timber and non-timber products. As a consequence of this demand, some native species have come to be brink of extinction.

The production of seedlings of native forest species is necessary for both commercial production and implantation, with a view to recovering the degraded areas and restoring forests and thus reducing the pressure on native forests. To achieve the objectives of planting, however, there is a need for research and development of tools and techniques to improve the production of seedlings of these species, at competitive costs and quality (Santos et al., 2006).

Plathymenia foliolosa Benth (vinhático) is a typical species of the Atlantic Forest, with high economic potential for timber production and recovery of degraded areas (Oliveira et al., 1998); therefore, studies on this species aimed at the optimization of seedling production techniques are highly desirable. It is a heliophite species, with irregular occurrence and discontinuous in area of occurrence (Souza and Lorenzi, 2008). The wood of this species is suitable for luxury furniture, decorative slabs, panels, etc. and is used in manufacturing of interior finishes, frames, blinds, ceilings, floorboards, boards, doors, and wine barrels (Lorenzi, 2002).

Due to the lack of silvicultural information and greater operational control of the technique, seedling production of vinhático is achieved using seeds, which has limited the commercial production of the seedlings'. Although the seed does not have dormancy, it has a low germination rate $(20 \%)$ (Lorenzi, 2002). According to Simão et al. (2007), other factors also complicate the propagation of seeds of forest species in nurseries, such as the definition of the ideal time of seed collection as well as the compatibility between the maturity of the fruit and that of the seed. In this context, vegetative propagation emerged as an alternative to seed production, gaining particular importance in the multiplication of a heterozygous genotype with characteristics considered superior(Paiva and Gomes, 2005).
In the case of Brazil, the development of intensive clonal forestry has been focused mainly on species of the genus Eucalyptus; however, there are experiments with vegetative propagation in some native species where clonal forestry programs are under development with different degrees of advancement (Xavier et al., 2013). Little or almost nothing is known about mini-cutting as a technique of vegetative propagation applied to native forest species, both experimentally and commercially.

One factor that affects rooting is the reduction in the leaf area. This is because in some species, the presence of leaves or a part of them, contributes to the rooting of mini-cuttings since the leaf area is essential for the accomplishment of photosynthesis and is, therefore, fundamental to the growth of the root system (Hartmann et al., 2011).

The objective of this work was to evaluate the production and survival of mini-stumps in mini-clonal hedge and the effect of foliar reduction of mini-cuttings on rooting and growth of saplings of Plathymenia Foliolosa.

\section{MATERIALS AND METHODS}

\section{1 - Establishment and maintenance of the mini- clonal hedge}

Six progenies of Plathymenia foliolosa Benthwere obtained from the cities of Laranjal (P01), Reduto (P03), Brás Pires (P19), Porto Firme (P21), Ponte Nova (P45), and Amparo do Serra (P53). The selection of the matrices and the collection of the seeds were made by the Forest Research Society -SIF/University of Viçosa. The establishment of the seedlings and mini-clonal hedge were made at the Research Center of the Forestry Engineering Department of the Federal University of Viçosa, in the city of Viçosa-MG.

The mini-clonal hedge was established in a semihydroponic system using a suspended bed under cover with transparent polyethylene plastic. The sand bed consisted of a cement-asbestos gutter, 7.5-m long, 0.8-m wide, and $25-\mathrm{cm}$ deep, containing inside sand to support the ministumps that were allocated in the spacing of $10 \times 10 \mathrm{~cm}$, containing a total of 96 mini-stumps per progeny. The mineral nutrition of the mini-stumps was made by dripping fertigation, distributed four times a day, in a total daily flow of $4 \mathrm{Lm}^{-2}$.

The nutrient solution used in the fertirrigation consisted of the following concentrations of the salts: calcium nitrate (0.920 $\left.\mathrm{g} \mathrm{L}^{-1}\right)$, potassium chloride $\left(0.240 \mathrm{~g} \mathrm{~L}^{-1}\right)$, potassium 
nitrate $\left(0.140 \mathrm{~g} \mathrm{~L}^{-1}\right)$, monoammonium phosphate $(0.096$ $\left.\mathrm{g} \mathrm{L}^{-1}\right)$, boronic acid $\left(2,800 \mathrm{mg} \mathrm{L}^{-1}\right)$, zinc sulfate $(0.480 \mathrm{mg}$ $\left.\mathrm{L}^{-1}\right)$, magnesium sulfate $\left(0.364 \mathrm{~g} \mathrm{~L}^{-1}\right)$, hydroferro manganese (1,120 $\left.\mathrm{mg} \mathrm{L}^{-1}\right)$, copper sulfate $\left(0.100 \mathrm{mg} \mathrm{L}^{-1}\right)$, and sodium molybdate $\left(0.040 \mathrm{mg} \mathrm{L}^{-1}\right)$. The electrical conductivity of the nutrient solution was maintained at $2.0 \mathrm{mS} \mathrm{m}^{-2}$ at $25^{\circ} \mathrm{C}$ (Borges et al., 2011).

\section{2 - Production and survival of mini-stumps}

The six progenies obtained for this experiment were distributed in a randomized block experimental design and were organized into four blocks, with 24 mini-stumps of each progeny per block. After the ministumps were acclimatized in the sand bed (45 days after establishment), apical pruning was done $10 \mathrm{~cm}$ from the base to stimulate the growth of shoots to generate mini-cuttings for later staking.

The evaluation of mini-stump production and survival was done every 30 days, by checking for the existence of shoots with minimum size for mini-cuttings, the number of shoots of each progeny per block, and the number of surviving mini-stumps of each progeny as a function of four successive prunings.

\section{3 - Influence of leaf reduction on the development of mini-cuttings}

In order to evaluate the influence of leaf reduction on the development of mini-cuttings of Vinhático, apical mini-cuttings were used with heights varying from 8 to $10 \mathrm{~cm}$, and treatments varying from $100 \%$ leaf reduction (without leaf) to $75 \%$ leaf reduction and no leaf reduction (whole leaf).

The bases $(2 \mathrm{~cm})$ of the mini-cuttings were immersed in IBA solution ( $\left.2000 \mathrm{mgL}^{-1}\right)$ for a period of 10 seconds and then staked in $55 \mathrm{~cm}^{3}$ tubes containing commercial BioPlant ${ }^{\circledR}$ substrate (Main raw material: fiber and powder of coconut Aggregates: Pinus bark, rice husk, vermiculite and nutrients technical characteristics: $\mathrm{pH}$ : 6.0-6.5/ EC: $0.5-1.0$ (1:5). The base mineral nutrition used in the substrate was composed of simple superphosphate $\left(8.00 \mathrm{~kg} \mathrm{~m}^{-3}\right)$ and osmocot in formulation 16-06-10 (0.3 $\mathrm{kg} \mathrm{m}^{-3}$ ) (Lang et al., 2011; Dias et al., 2012).

The mini-cuttings were staked in a greenhouse with relative air humidity above $85 \%$ and temperature between 20 and $30^{\circ} \mathrm{C}$. After 60 days, the mini-cuttings were transferred to the shade house with $50 \%$ shading, where they remained for 15 days, when they were transferred to full sun until completion of 90 days. At the exit of the greenhouse and at the exit of the shade house, $3 \mathrm{~mL} \mathrm{~mol}^{-1}$ of monoammonium phosphate (2.0 $\left.\mathrm{g} \mathrm{L}^{-1}\right)$ was used as cover fertilizer.

The design used to evaluate the influence of leaf reduction on mini-cuttings of Vinhático was randomized blocks containing six progenies organized in three blocks, with 15 mini-cuttings of each degree of leaf reduction (whole leaf, 75\% leaf reduction, and 100\% reduction). The data were interpreted statistically by means of analysis of variance and the means test (Tukey test at $5 \%$ of probability), by using the software Statistic 8.0. During the period that the mini-cuttings were maintained in the greenhouse (60 days) and when transferred to the shade house (50\%) shading for 15 days, survival (Sob), root observed at the lower end of the tube (ROEIT), and vigor were evaluated. For vigor, scores of 1 to 3 were assigned (bad, good, and great). After the full-sun stage maintained for 15 days, survival, rooting, height, lap diameter, vigor, number of roots, root length, and dry mass of shoot and root were evaluated.

For the purposes of the evaluations, mini-cuttings were considered rooted when roots were greater than or equal to $0.5 \mathrm{~cm}$ and shoots had sprouted in the aerial part. For counting the number of roots, we considered the roots emitted directly from the base of the minicuttings. For the measurement of height and lap diameter, mini-cuttings with roots and shoots were considered, the height being determined with a millimeter ruler, from the substrate level to the tip of the last leaf, and the neck diameter was determined in level with a precision digital caliper. In order to obtain the dry mass, the aerial part was individualized from the root, and both were kept in a greenhouse at a temperature of $65^{\circ} \mathrm{C}$ until constant weight was achieved.

\section{RESULTS}

\section{1 - Production and survival of the mini-stumps}

The survival results of the mini-stumps show that there was no significant difference in the first minicuttings collection (Table 1). For the following collections $(2,3,4)$, the P03 and P19 progenies had the highest percentage of survival (64.5\% and $61.5 \%$, respectively), while the progenies P01 (32.3\%) and P45 (25\%) exhibited the lowest values for this evaluation. This leads us to assume greater sensitivity of these progenies to 
the effects of management and environmental conditions in the mini-clonal hedge. On observing the collections of mini-cuttings from each progeny, we found that the first collection had $100 \%$ survival, differentiating it from the others. On the other hand, the subsequent collections $(2,3$, and 4$)$ did not show any difference between them, with a lower percentage of survival. Survival stabilization tended to occur due to the adaptation of mini-stumps to the successive collections (3 and 4).

Analyzing the number of mini-cuttings per ministumps among the collections (Table 1) shows that there was no difference between the collections 1,3 , and 4 . The second collection was different from the others, and the $\mathrm{P} 01$ progeny showed high productivity (4.8 mini-cuttings per mini-stumps) while P03 progeny had low productivity (with a mean number of 1.3). Observing the average number of mini-cuttings of each progeny, the second collection had the highest number of mini-cuttings in almost all the collections, except for the P03 progeny, which showed high production in the 3 rd collection.

The average number of mini-cuttings per ministumps was 2.0, ranging from 0.8 (for P53 progeny in collection 1) to 4.8 (for P01 progeny in collection 2), with the average productivity of the mini-stumps per $\mathrm{m}^{2}$ of the mini-garden being 120 mini-cuttings for each collection.

\section{2 - Influence of leaf reduction}

The variables analyzed at the exit of the greenhouse, shade house, and full sun did not reveal any interaction between the factors of leaf reduction and progenies, with significance $(\mathrm{F}<0.05)$ only of the independent factors.

Table 2 shows that there was a difference between the progenies with respect to the variables analyzed at the exit of the greenhouse, reaching averages ranging from $48.9 \%$ (P53 progeny) to $65.9 \%$ (progeny P19). For root exposition at the lower end of the tube, the averages ranged from $7.4 \%$ (P21 progeny) to $27.7 \%$ (P03 progeny). Vigor was high in progenies with very vigorous mini-cuttings, such as progenies P03 and P19, and low in progenies with stakes, such as progenies P45 and P53.

The results, according to Table 2 show that for root length, the $\mathrm{P} 03, \mathrm{P} 21, \mathrm{P} 45$, and $\mathrm{P} 53$ progenies obtained superior results than the others, when in full sun. The progeny P53 had a larger neck diameter $(1.67 \mathrm{~mm})$ and the P01 progeny had the smallest diameter $(0.94 \mathrm{~mm})$. The dry mass of the shoot varied from $0.51 \mathrm{~g}$ (P01 progeny) to $1.51 \mathrm{~g}$ (P03 progeny), and the dry root mass ranged from $0.28 \mathrm{~g}$ (P01 progeny) to $0.74 \mathrm{~g}$ (P19 progeny) (Table 2). However, for the number of roots observed in the mini-cuttings, no difference was noted between the progenies.

For the results of leaf reduction of mini-cuttings, in all propagation environments (Tables 3 and 4), treatments with whole leaves and with $75 \%$ of reduction did not present significant differences among them for the characteristics evaluated; however, mortality of mini-cuttings was $100 \%$ when total reduction of its leaf was made.

\section{DISCUSSION}

\section{1 - Production and survival of mini-stumps}

According to Xavier et al. (2013), the conditions of high physiological vigor of mini-cuttings, resulting from the management system adopted in the mini-clonal hedge, are also a factor of great importance in the vegetative propagation. Dias et al. (2012), evaluating the survival of Angico-vermelho's mini-stumps, observed a variation between $84 \%$ and $98 \%$, which exceed the range noted found in this study. Quadros et al. (2011) found similar results with Erva-mate, with the authors observing a survival of $58.5 \%$ mini-stumps. Freitas (2012) evaluated mini-garden of Ipê-roxo (Handroanthus heptaphyllus) and observed $100 \%$ survival of the ministumps. Cunha et al. (2008) also found 100\% survival of Cedrela fissilis ' mini-stumps, after four collections, which is the same as that noted in the present study. Stuepp et al. (2016) worked with Paulownia fortunei var. Mikado and observed that mini-stumps showed $100 \%$ survival after five collections and an average yield of 76 to $114 \mathrm{mini}$-cuttings $/ \mathrm{m}^{2} /$ month, results that exceed those found in this study.

Proper management and nutrition are very important for the maintenance of the vigor of the mini-stumps, since these are two of the main factors that affect the supply of propagules (Hartmann et al., 2011). The good productivity of the mini-stumps during the experimental period of this study is due to its good nutritional status, which is important not only for vegetative vigor and sprout production but also to obtain satisfactory rates of rooting (Alfenas et al., 2009; Xavier et al., 2013). Gatti (2002) worked with teak (Tectona grandis) and achieved an average number of 1.7 mini-cuttings per 
Table 1 - Survival of mini-stumps and number of mini-cuttings by mini-stumps of six progenies of Vinhático (Plathymenia foliolosa) due to successive collections.

Tabela 1 - Sobrevivência (Sob) das minicepas e número de miniestacas por minicepas de seis progênies de vinhático (Plathymenia foliolosa) em função das coletas sucessivas.

\begin{tabular}{|c|c|c|c|c|c|}
\hline \multirow[t]{2}{*}{ Characteristics } & \multirow[t]{2}{*}{ Progenies } & \multicolumn{4}{|c|}{ Collections } \\
\hline & & 1 & 2 & 3 & 4 \\
\hline \multirow{6}{*}{ Sob (\%) } & P01 & $100 \mathrm{aA}^{*}$ & $46,28 \mathrm{bcB}$ & $32,29 \mathrm{bcB}$ & $32,29 \mathrm{bcB}$ \\
\hline & P03 & $100 \mathrm{aA}$ & $77,08 \mathrm{aB}$ & $64,58 \mathrm{aB}$ & $64,58 \mathrm{aB}$ \\
\hline & P 19 & $100 \mathrm{aA}$ & 73,96 aB & $61,46 \mathrm{aB}$ & $61,46 \mathrm{aB}$ \\
\hline & P2 1 & $100 \mathrm{aA}$ & $60,42 \mathrm{abB}$ & $48,96 \mathrm{abB}$ & $47,92 \mathrm{abB}$ \\
\hline & P45 & $100 \mathrm{aA}$ & $33,33 \mathrm{cB}$ & $25,00 \mathrm{cB}$ & $25,00 \mathrm{cB}$ \\
\hline & P53 & $100 \mathrm{aA}$ & $62,50 \mathrm{abB}$ & $52,08 \mathrm{abB}$ & $52,08 \mathrm{abB}$ \\
\hline \multirow{6}{*}{$\begin{array}{l}\mathrm{N}^{\circ} \text { Mini-cuttings } \\
\text { per mini-stumps }\end{array}$} & P01 & $1,66 \mathrm{aB}$ & 4,83 aA & $2,38 \mathrm{aB}$ & $2,30 \mathrm{aB}$ \\
\hline & P03 & $1,25 \mathrm{aA}$ & $1,28 \mathrm{cA}$ & $1,62 \mathrm{aA}$ & $1,46 \mathrm{aA}$ \\
\hline & P 19 & $1,03 \mathrm{aA}$ & $2,31 \mathrm{bcA}$ & $1,96 \mathrm{aA}$ & $2,23 \mathrm{aA}$ \\
\hline & P2 1 & $1,25 \mathrm{aA}$ & $2,41 \mathrm{bcA}$ & $1,96 \mathrm{aA}$ & $1,86 \mathrm{aA}$ \\
\hline & $\mathrm{P} 45$ & $1,25 \mathrm{aB}$ & $3,65 \mathrm{abA}$ & 2,42 aAB & $1,60 \mathrm{aB}$ \\
\hline & P53 & $0,83 \mathrm{aC}$ & $3,00 \mathrm{bA}$ & $2,21 \mathrm{aAB}$ & $1,64 \mathrm{aBC}$ \\
\hline
\end{tabular}

Means with the same lowercase letter in the column within the same collection and averages with the same capital letter in the row within the same progeny do not differ from each other, by the Tukey test at $5 \%$ probability.

Table 2 - Mean values of survival characteristics (Sob), roots observed at the bottom of the container (ROEIT), rooting (ER), root length (ComR), collar diameter (DC), number of roots (NR), and shoot dry mass (SDM) and root system (MSR) of six progenies Plathymenia foliolosa, greenhouse exit (CV) and full sun, depending on the leaf reduction.

Tabela 2 - Valores médios das características de sobrevivência (Sob), raiz observada na extremidade inferior do tubete (ROEIT), enraizamento (ER), comprimento da raíz (ComR), diâmetro de colo (DC), número de raízes (NR), e massa seca da parte aérea (MSPA) e do sistema radicular (MSR) de seis progênies de Plathymenia foliolosa, na saída da casa de vegetação (CV) e pleno sol, em função da redução foliar.

\begin{tabular}{|c|c|c|c|c|c|c|c|c|}
\hline \multirow[t]{2}{*}{ Progeny } & \multicolumn{3}{|c|}{ Greenhouse } & \multicolumn{5}{|c|}{ Full sun } \\
\hline & Sob (\%) & ROEIT (\%) & Vigor & ComR & $\mathrm{DC}$ & NR & MSPA & MSR \\
\hline P01 & $59,56 \mathrm{ab}^{*}$ & $23,70 \mathrm{a}$ & $0,79 \mathrm{ab}$ & $3,58 b^{*}$ & $0,94 \mathrm{~b}$ & $1,42 \mathrm{a}$ & $0,51 \mathrm{~b}$ & $0,28 \mathrm{~b}$ \\
\hline P03 & $58,52 \mathrm{ab}$ & $23,15 \mathrm{a}$ & $0,94 \mathrm{a}$ & $6,60 \mathrm{a}$ & $1,59 \mathrm{ab}$ & $2,62 \mathrm{a}$ & $1,51 \mathrm{a}$ & $0,7 \mathrm{ab}$ \\
\hline P19 & $65,92 \mathrm{a}$ & $15,31 \mathrm{ab}$ & $0,89 \mathrm{ab}$ & $5,27 \mathrm{ab}$ & $1,57 \mathrm{ab}$ & $1,84 \mathrm{a}$ & $1,00 \mathrm{ab}$ & $0,74 \mathrm{a}$ \\
\hline P2 1 & $61,49 \mathrm{ab}$ & $11,11 \mathrm{ab}$ & $0,80 \mathrm{ab}$ & $6,57 \mathrm{a}$ & $1,52 \mathrm{ab}$ & $3,11 \mathrm{a}$ & $1,18 \mathrm{ab}$ & $0,52 \mathrm{ab}$ \\
\hline P 4 & $51,49 \mathrm{ab}$ & $11,11 \mathrm{ab}$ & $0,76 \mathrm{ab}$ & $6,67 \mathrm{a}$ & $1,58 \mathrm{ab}$ & 3,19 a & $0,67 \mathrm{~b}$ & $0,37 \mathrm{ab}$ \\
\hline P53 & $48,88 \mathrm{~b}$ & $7,41 \mathrm{~b}$ & $0,61 \mathrm{~b}$ & $6,67 \mathrm{a}$ & $1,67 \mathrm{a}$ & $2,89 \mathrm{a}$ & $0,76 \mathrm{ab}$ & $0,31 \mathrm{ab}$ \\
\hline
\end{tabular}

Averages with the same letter do not differ from each other, by the Tukey test at $5 \%$ probability.

Table 3 - Survival (SOB), roots observed at the bottom of the container (ROEIT) and force six progenies Plathymenia foliolosa, greenhouse exit (CV), shade house (CS) depending on the leaf reduction.

Tabela 3 - Sobrevivência (SOB), raiz observada na extremidade inferior do tubete (ROEIT) e vigor de seis progênies de Plathymenia foliolosa, na saída da casa de vegetação (CV), casa de sombra (CS) em função redução foliar.

\begin{tabular}{|c|c|c|c|c|c|c|}
\hline \multirow[t]{2}{*}{ Treatments } & \multicolumn{3}{|c|}{ Greenhouse (60 days) } & \multicolumn{3}{|c|}{ Shade House ( 75 days) } \\
\hline & Sob $(\%)$ & ROEIT (\%) & Vigor & Sob $(\%)$ & ROEIT (\%) & Vigor \\
\hline Without Leaf & $0,00 \mathrm{~b}^{*}$ & $0,00 \mathrm{~b}$ & $0,00 \mathrm{~b}$ & $0,00 \mathrm{~b}$ & $0,00 \mathrm{~b}$ & $0,00 \mathrm{~b}$ \\
\hline Reduction $75 \%$ & 84,70 a & 19,93 a & $1,13 \mathrm{a}$ & 60,77 a & 36,19 a & $1,22 \mathrm{a}$ \\
\hline Whole Leaf & 88,41 a & $25,97 \mathrm{a}$ & $1,26 \mathrm{a}$ & 59,95 a & $37,30 \mathrm{a}$ & $1,22 \mathrm{a}$ \\
\hline
\end{tabular}

Averages with the same letter do not differ from each other, by the Tukey test at 5\% probability.

mini-stumps at the end of six collections, which is a result similar to those obtained in this one. Ferreira et al. (2010), working with Leiteiro's mini-cuttings (Sapium glandulatum), reported values lower than those of this study, with productivity of mini-cuttings ranging from 1.4 to 2.2 .

The low average number of mini-cuttings in the first collection can be attributed to the stress caused 
Table 4 - Survival (SOB), roots observed at the bottom of the container (ROEIT), rooting (ER), height (H), root length (ComR), collar diameter (DC), number of roots (NR), and shoot dry mass (SDM) and root system (MSR) of six progenies Plathymenia foliolosa in open sun depending on the leaf reduction.

Tabela 4 - Sobrevivência (SOB), raiz observada na extremidade inferior do tubete (ROEIT), enraizamento (ER), altura $(H)$, comprimento da raíz (ComR), diâmetro de colo (DC), número de raízes (NR), e massa seca da parte aérea (MSPA) e do sistema radicular (MSR) de miniestacas de Plathymenia foliolosa, em pleno sol em função redução

\begin{tabular}{lccccccccc}
\hline \multirow{2}{*}{ Treatments } & \multicolumn{7}{c}{ Full sun $(90$ days $)$} \\
\cline { 2 - 8 } & Sob(\%) & ER(\%) & Vigor & H(cm) & ComR(cm) & DC(mm) & NR & MSPA(g) & MSR(g) \\
\hline Without Leaf & $0,00 \mathrm{~b}$ & $0,00 \mathrm{~b}$ & $0,00 \mathrm{~b}$ & $0,00 \mathrm{~b}$ & $0,00 \mathrm{~b}$ & $0,00 \mathrm{~b}$ & $0,00 \mathrm{~b}$ & $0,00 \mathrm{~b}$ & $0,00 \mathrm{~b}$ \\
Reduction75\% & $31,02 \mathrm{a}$ & $30,09 \mathrm{a}$ & $1,05 \mathrm{a}$ & $8,12 \mathrm{a}$ & $8,61 \mathrm{a}$ & $2,16 \mathrm{a}$ & $3,72 \mathrm{a}$ & $1,21 \mathrm{a}$ & $0,73 \mathrm{a}$ \\
Whole Leaf & $31,77 \mathrm{a}$ & $31,39 \mathrm{a}$ & $1,06 \mathrm{a}$ & $8,23 \mathrm{a}$ & $9,07 \mathrm{a}$ & $2,28 \mathrm{a}$ & $3,82 \mathrm{a}$ & $1,61 \mathrm{a}$ & $0,73 \mathrm{a}$ \\
\hline
\end{tabular}

Averages with the same letter do not differ from each other, by the Tukey test at 5\% probability.

to the mini-stumps by apical pruning, due to the initial difficulty of adapting the species to the semi-hydroponic conduction system as well as the presence of buds that did not grow due to apical dominance (Wendling and Souza Júnior, 2003; Freitas, 2012; Mantovani et al., 2017). Silva et al. (2012), working with Cedro Australiano (Toona ciliata), achieved a superior result than that obtained in this study, with an average of 3.5 mini-cuttings per mini-stumps, in a sand bed. Xavier et al. (2003), working with vegetative propagation of Cedro Rosa (Cedrela fissilis), obtained 1.3 shoots per mini-stumps, which is lower than that achieved in this study.

\section{2 - Influence of leaf reduction}

The differences observed between the progenies can be explained by the genetic variability between them, i.e., the differences in the genotypes between the progenies and also among the progenies. According to Xavier et al. (2013), the phenotypic variations between plants propagated by seed result from the interaction between the genotypic factors, environmental factors, and the interaction between these factors. As in the experiment, the progenies were all subject to the same environmental condition; the variations observed in the evaluated characteristics come mainly from the difference between the genotypes or due to the differences between the endogenous rhythms of the plants, which are related to physiological and morphological factors (Mankessi et al., 2009).

The percentage of survival at the exit of the greenhouse, although not representing a concrete result of the adventitious rooting of the mini-cuttings, is relevant because it shows, in part, the efficiency of the control of the environmental conditions (humidity and temperature) in the greenhouse as well as the vigor of the mini-cuttings used (Titon et al., 2002). Badilla et al. (2016) working with Tectona grandis observed $95.4 \%$ survival after 30 days in a greenhouse, a percentage higher than found in this study. Pires et al. (2013) reported findings similar to those of this study, which recorded an average of $50 \%$ survival of mini-cuttings of Araucaria angustifolia at the exit of the greenhouse. Faganello et al. (2015) found a 43.7\% survival rate for Cordia trichotoma which is similar to that obtained in this one. There was an increase in mortality at the exit from the greenhouse until the final stage in full sun, which may be partly because the volume of root formed was not sufficient to maintain the survival of the seedlings.

As observed in the results of the present study, the total leaf reduction caused $100 \%$ mortality of mini-cuttings, probably due to the non-production of carbohydrates resulting from photosynthesis and auxins produced by leaves and apical buds that are essential for rooting and consequently their survival (Taiz and Zeiger, 2006; Hartman et al., 2011; Xavier et al., 2013). Therefore, it is advisable not to reduce the leafarea for mini-cuttings of Plathymenia foliolosa, because mini-cuttings with the whole leaf allowed a similar or superior development to the mini-cuttings with reduced leaf, besides not causing stress in the mini-cuttings due to the leaf cut.

Leaf reduction aims to reduce the area of transpiration and avoid the umbrella effect, as a physical barrier provided by the leaves of the mini-cutting, thereby preventing the wetting of the substrate. However, leaf cutting may be a gateway for the entry of pathogenic microorganisms during the rooting phase, due to the injuries caused in the leaves of the mini-cuttings (Alfenas et al., 2009). Santana et al. (2010) evaluated the effect of leaf reduction $(0 \%, 25 \%, 50 \%$, and $75 \%)$ on the production of Eucalyptus clone seedlings, demonstrating that the $0 \%$ leaf reduction level can be adopted for most clones evaluated. Souza et al. (2013) with the 
objective of evaluating the influence of 12 mini-cuttings patterns on Eucalyptus grandis Hill $\times$ E. urophylla rooting, concluded that non-reduction of leaves was the most suitable procedure for seedling production in the evaluated clones. Correia et al. (2015), working with different types of mini-cuttings of Eucalyptus clones, found different results in the survival of minicuttings' types with leaf reduction at the exit of the greenhouse and at the exit of the shade house.

Paiva and Gomes (2005) and Dantas et al. (2016) reported that the presence of leaves and buds on the cuttings exerts a positive influence on rooting, since they synthesize essential carbohydrates, which provide energy through the photosynthetic process. Leaves and buds are fundamental to the development of the cutting, because they are sites with natural production of phytogulators such as auxin. This hormone is responsible for promoting cell division and early adventitial root formation, aiding in the development and growth of plants (Taiz and Zeiger, 2004).

According to Souza (2012), with a view to increasing commercial productivity and reducing costs, these results translate into benefits in the process of production of clonal seedlings, both ergonomically and economically, by reducing repetitive efforts by people to prepare mini-cuttings and reducing a stage in the process of production of seedlings by cutting, respectively.

\section{CONCLUSIONS}

Leaf maintenance is important for the rooting and survival of Plathymenia foliolosa mini-cuttings, especially without leaf reduction, which will facilitate mainly to the practicality use of the plant, optimization of seedlings preparation time and reduction of seedlings costs. The progenies studied have the potential for the regeneration of the mini-stumps, thus allowing successive collections of juvenile shoots in the mini-garden.

\section{REFERENCES}

Alfenas AC, Zauza EAV, Mafia RG, Assis TF. Clonagem e doenças do eucalipto. $2^{\mathrm{a}}$. ed. Viçosa, MG: Universidade Federal de Viçosa; 2009. 500p.

Badillla Y, Xavier A, Murillo O, Paiva HN. Eficiência do AIB no enraizamento de miniestacas de clones de Teca (Tectona grandis Linn F.). Revista Árvore. 2016;40:477-85.
Borges SR et al. Enraizamento de miniestacas de clones híbridos de Eucalyptus globulus. Revista Árvore. 2011;35:425-34.

Correia ACG, Xavier A, Dias PC, Titon M, Santana RC. Redução foliar em miniestacas e microestacas de clones híbridos de Eucalyptus globulus. Revista Árvore. 2015;39:295-304.

Cunha ACMCM, Wendling I, Souza Júnior L. Miniestaquia em sistema de hidroponia e em tubetes de corticeira-do-mato. Ciência Florestal. 2008;18:85-92.

Dantas AK, Majada J, Dantas FK, Delatorre C, Granda V, Vallejo P, Feito I. Enraizamento de miniestacas de clones híbridos de Castanea sativa Mill. Revista Árvore. 2016;40:465-75.

Dias PC, Xavier A, Oliveira LS, Paiva HN, Correia ACG. Propagação vegetativa de progênies de meios-irmãos de angico-vermelho (Anadenanthera macrocarpa (Benth) Brenan) por miniestaquia. Revista Árvore. 2012;36:389-99.

Dias PC, Xavier A, Oliveira LS, Correira ACG, Barbosa GA. Tipo de miniestaca e de substrato na propagação vegetativa de Angico-vermelho (Anadenanthera macrocarpa (Benth.) Brenan). Ciência Florestal. 2015;25:909-19.

Faganello LR, Dranski JAL, Malavasi UC, Malavasi MM. Efeito dos ácidos indolbutírico e naftalenoacético no enraizamento de estacas semilenhosas de Cordia trichotoma (Vell.) Arrab. ex Steud. Ciência Florestal. 2015;25:863-71.

Ferreira BGA, Zuffellato-Ribas KC, Wendling I, Koehler HS, Nogueira AC. Miniestaquia de Sapium glandulatum (Vell.) Pax com o uso de ácido indolbutírico e ácido naftalenoacético. Ciência Florestal. 2010;20:19-31.

Freitas TP. Propagação de ipê-roxo (Handroanthus heptaphyllus Mattos) por miniestaquia [dissertação]. Campos dos Goytacazes: Universidade Estadual do Norte Fluminense Darcy Ribeiro; 2012.

Gatti KC. Propagação vegetativa de pau mulato (Calycophyllum spruceanum (Benth) K. Schum.) jequitibá (Cariniana estrellensis (Raddi) Kuntze) e Teca (Tectona grandis Linn. F.) por miniestaquia 
[dissertação]. Viçosa, MG: Universidade Federal de Viçosa; 2002.

Hartmann HT, Kester DE, Davies FT Jr, Geneve RL. Plant propagation: principles and practices. 8th. ed. São Paulo: Prentice-Hall; 2011.

Lang A. et al. Aplicação de fertilizante de liberação lenta no estabelecimento de mudas de ipê-roxo e angico-branco em área de domínio ciliar. Revista Floresta. 2011;41:271-6.

Lorenzi H. Árvores brasileiras: manual de identificação de plantas arbóreas do Brasil. $4^{\mathrm{a}}$.ed. Nova Odessa: Plantarum; 2002. 290p.

Mankessi F, Saya A, Baptiste C, NourissierMountou S, Monteuuis O. In vitro rooting of genetically related Eucalyptus urophylla $\times$ Eucalyptus grandis clones in relation to the time spent in culture. Trees. 2009;23:931-40.

Mantovani N, Roveda M, Tres L, Fortes FO, Grando MF. Cultivo de Canafístula (Peltophorum dubium) em minijardim clonal e propagação por miniestacas. Ciência Florestal. 2017;27:225-36.

Oliveira CEV, Oliveira GM, Almeida DS, Zago AR, Ferreira GW. Comportamento de espécies florestais nativas em plantios homogêneos na região serrana. Revista Floresta e Ambiente. 1998;5:216-24.

Paiva NH, Gomes JM. Propagação vegetativa de espécies florestais. Viçosa, MG: Universidade Federal de Viçosa; 2005. 46p. (Cadernos didáticos, 83).

Pires PP, Wendling I, Brondani G. Ácido indolbutírico e ortotropismo na miniestaquia de Araucaria angustifolia. Revista Árvore, 2013;37:393-9.

Quadros KM, Comiran M, Bisognin DA, Rauber M, Fischer H. Produção de miniestacas e microestacas em jardim clonal e vigor e sobrevivência das minicepas e microcepas de erva-mate.In: Resumo do $15^{\circ}$ Simpósio de Ensino, Pesquisa e Extensão. Santa Maria: Centro Universitário Franciscano - UNIFRA; 2011.

Santana RC, Dutra TR, Carvalho Neto JP, Nogueira GS, Grazziotti PH, Barros Filho NF.
Influence of leaf area reduction on clonal production of Eucalyptus seedling. Cerne. 2010;16:251-7.

Santos PS, Lisboa AC, Neto SNO, Grugiki MA, Ferreira MA. Qualidade de mudas de quatro espécies florestais produzidas em diferentes tubetes. Revista Floresta e Ambiente, 2006;13:6978.

Silva MPS, Barroso DG, Souza JS, Ferreira DA, Carneiro JGA. Enraizamento de miniestacas e produtividade de minicepas de Cedro Australiano manejadas em canaletões e tubetes. Ciência Florestal. 2012;22:703-13.

Simão E, Nakamura AT, Takaki M. Época de colheita e capacidade germinativa de sementes de Tibouchina mutabilis (Vell.) Cogn. (Melastomataceae). Biota Neotropica. 2007;7:67-73.

Souza CC. Padrões de miniestacas e densidade de minicepas na propagação clonal de Eucalyptus grandis $\mathrm{x}$ E. urophylla [dissertação] Viçosa, MG: Universidade Federal de Viçosa; 2012.

Souza CC, Xavier A, Leite FP, Santana RC, Leite HG. Padrões de miniestacas e sazonalidade na produção de mudas clonais de Eucalyptus grandis Hill X E.urophylla S. T. Black. Revista Árvore. 2013;37:6777.

Souza VC, Lorenzi H. Botânica sistemática: guia ilustrado para identificação das famílias de Fanerógamas nativas e exóticas no Brasil, baseado em APG II. $2^{\text {a }}$.ed. Nova Odessa: Instituto Plantarum; 2008.

Stuepp CA, Zuffellato-Ribas KC, Koehler HS, Wendling I. Enraizamento de miniestacas de Paulownia fortunei var. mikado provenientes de minijardim. Revista Árvore. 2015;39:497-504.

Taiz L, Zeiger E. Fisiologia vegetal. $3^{\text {a }}$.ed. Porto Alegre: Artmed; 2004.

Taiz L, Zeiger E. Fisiologia vegetal. Porto Alegre: Artmed; 2006.

Titon M, Xavier A, Otoni WC. Dinâmica do enraizamento de microestacas e miniestacas de clones de Eucalyptus grandis. Revista Árvore. 2002;26:665-73. 
Wendling I, Souza Júnior L. Propagação vegetativa de erva-mate (Ilex paraguariensis Saint Hilaire) por miniestaquia de material juvenil. In: Anais do $3^{\circ}$. Congresso Sul-Americano da Erva-Mate. Chapecó: Epagri; 2003.

Xavier A, Santos GA, Wendling I, Oliveira ML.
Propagação vegetativa de cedro-rosa por miniestaquia. Revista Árvore. 2003;27:139-43.

Xavier A, Wendling I, Silva RL. Silvicultura clonal - Princípios e técnicas. $2^{\mathrm{a}}$.ed.Viçosa, MG:

Universidade Federal de Viçosa; 2013. 280p.

\section{ERRATA}

No artigo "PRODUCTION OF MINI-CUTTINGS AND THE INFLUENCE OF LEAF REDUCTION ON ROOTING OF VINHÁTICO (Plathymenia foliolosa Benth.)”, publicado no número 4, volume 41, da Revista Árvore, onde se lê:

http://dx .doi.org/10.1590/1806-90882017000200002

L eia- s e:

http://dx .doi.org/10.1590/1806-90882017000400002 